\title{
SOBÓR TRYDENCKI \\ A CZYTANIE PISMA ŚW. W JĘZYKU LUDOWYM
}

Dziś, po 400 latach, warto sobie przypomnieć obrady soboru trydenckiego w sprawie Pisma św.

Dnia 18 kwietnia $1546 \mathrm{r}$. powziął sobór na swym czwartym posiedzeniu kilka bardzo ważnych postanowień, odnoszących się do Ksiąg św., które według nauki Kościoła katolickiego nie są co prawda jedynym, jak twierdzili protestanci, ale jednak obok tradycji podstawowym źródłem objawienia Bożego. Ustalił więc sobór trydencki ostatecznie kanon i wbrew nauce Lutra i jego zwolenników przyznał księgom, tak zwanym deuterokanonicznym, eo do których w pierwszych wiekach chrześcijaństwa były pewne zastrzeżenia i wątpliwości, tę samą wartość i znaczenie, jak i protokanonicznym, to jest tym, które w Kościele były powszechnie uznawane jako święte i natchnione.

Aby uniknąć zamieszania przy wykładaniu Pisma św., które powstawało skutkiem powstawania nowych przekładów Biblii w języku łacińskim, postanowił sobór trydencki, aby przy publicznych czytaniach, rozprawach, kazaniach i wyjaśnieniach Pisma św. teologowie używali jedynie dawnej Wulgaty Hieronimowej, która uzyskała swą wyjątkową powage przez długowieczne używanie jej w Kościele łacińskim.

Dalej oświadczył sobór, że w tłumaczeniu Pisma św. uczonym katolickim nie wolno być zbyt swobodnym i jego właściwego sensu naciągać do własnych poglądów, lecz w rzeczach wiary i obyczajów obowiązkiem egzegety katolickiego jest iść wyłącznie za tym sensem, którego się trzymał i trzyma Kościół święty. Nie wolno też egzegetom wy jaśniać Pisma św. wbrew jednomyślnej zgodzie Ojców, choćby tego rodzaju wyjaśnienia nie miały nigdy być opublikowane.

Wydał tė sobór trydencki surowy zakaz drukarzom, by bez pozwolenia przełożonych kościelnych nie wydawali ksiąg Pisma św., ani też objaśnień do niego zwłaszcza bezimiennych, by tego rodzaju ksiązek nie zatrzymywali u siebie, ani ich nie sprzedawali, o ile wpierw nie zostaną zbadane i zatwierdzone przez Ordynariusza.

Niektórzy obecni na soborze biskupi życzyli sobie, by dekretem soborowym zabronić wiernym czytania Pisma św. w języku ludowym, ale tego zbyt daleko idącego zamiaru nie zdołali przeprowadzić i sobór nie wydał dekretu zabraniającego wiernym czytania Pisma św. w ich języku ojczystym. 
Sprawa bowiem czytania Pisma św. w języku ludowym znalazła na soborze, jak dowiadujemy się z jego aktów (Concilium Tridentinum t. XII, s. 528nn, Herder-Freiburg 1930), dwóch wybitnych obrońców w osobach kard. tryd. Krzysztofiora M a drutius a i teologa kard. Marcelego Cervina, nazwiskiem: Ge ntia n us $\mathrm{H}$ e $\mathrm{r} v$ e $\mathrm{t}$ us. Przemówienia tych dwóch teologów, wygłoszone w miesiącu marcu $1546 \mathrm{r}$. na soborze trydenckim w obronie czytania Pisma św. przez prostaczków w języku ludowym, są bardzo ciekawe i charakterystyczne i warto je, jak sądzę, przytoczyć $\mathrm{z}$ okazji czterowiekowego jubileuszu (w r. 1946). Z obu przemówień podamy tylko najważniejsze wyjątki.

Kard. Madrutius był zwolennikiem przekładów Pisma św. na języki nowożytne, podobnie jak to się działo w pierwszych wiekach chrześcijaństwa, kiedy to Pismo św. tłumaczono z języków oryginalnych hebrajskiego i greckiego na języki: łaciński, syryjski, koptyjski i inne. Pismo św. bowiem według św. Pawła (Rzym. 15, 4) zostało napisane, ,abyśmy przez cierpliwość i przez pociechę z Pisma nadzieję mieli“", a według tegoż Apostoła II Tym. 3, 16: „Wszelkie Pismo przez Boga natchnione pożyteczne jest do nauczania, do przekonywania, do napominania i do kształcenia w sprawiedliwości, aby człowiek Boży stał się doskonałym i do'wszelkiej dobrej sprawy wyćwiczonym“".

Zdaniem kardynała M. nie ma żadnego powodu, dla którego mielibyśmy-strzec przed ludem czytania Pisma św. w ich języku ojczystym. Czy może dlatego, pyta on, że mając klucz mądrości, sami nie wchodzimy (do Królestwa Bożego), a natomia'st innym, którzy chcą wejść, rękami i nogami przeszkaidzamy? Czemu mamy dawać prołestantom powód do zarzutów, że maluczkim, spragnionym wody zbawienia, zabraniamy czytania Pisma św., a zabraniamy dlatego, by nie dowiedzieli się z niego o našzych oszustwach? Czyż nie jesteśmy uczestnikami jednego chleba, czyż nie pijemy z tego samego kielicha? Czy nie mamy jednego ducha, jednej wiary, jednego chrutu, jednego Boga i Ojca naszego i jednej nadziei wiecznego dziedzictwa? Jeśli tedy chrześcijanie to wszystko mają wspólne, to dlaczego Ewangelia nie ma być wspólną własnością i służyć wszystkim do wspólnego użytku, to jest do wzrostu pobożności i do wyrobienia obyczajów wiszystkich chrześcijan? Czemuż nie mają mieć pobożni prostaczkowie, jednej będący $z$ nami religii i jednego Przymierza, mleka chrześcijańskiego, to jest Ewangelii ludowej, która by ich żywiła i powiększała z nami w Chrystusie? Czyż mając na uwadze słowa Zbawiciela: ,Nie dawajcie psom tego, co święte, ani rzucajcie pereł waszych przed wieprze!“ powstrzymywać ich będziemy od ezytania Ewangelii i usuwać będzie- 
my od ich ust ów chleb życia i zrozumienia, spadający $z$ nieba? Nie daj Boże, by domownicy Boży i jego synowie adoptowani, którzy razem z nami wołają „Abba, Ojcze“, by ci, mówię, których Chrystus odkupił nie znikomymi rzeczami, jak srebrem i złotem, lecz wielką ceną Swojej krwi, mieli być dla nas psami i wieprzami? Nie daj tego Boże, byśmy tego nie opowiadali po dachach, cośmy słyszeli, i to w jakimkolwiek języku, gdyż dlatego spłynął do nas z nieba Duch Boży w językach ognistych i jakby łuski spadły z oczu naszych, aby oczy nasze nie były dłużej zatrzymywane, lecz byśmy widzieli i by przez dar Boży niemal wszystkie tajemnice Boże istały dla nas otworem?

Żadną miarą! To jest bowiem odwieczny los Ewangelii, że jest ona dla jednych upadkiem, a dla innych zmartwychwstaniem, dla jednych zgorszeniem i głupstwem, a dla innych mocą Bożą ku zbawieniu, dla jednych zapachem życia ku żywotowi, a dla innych zapachem śmierci na śmierć. Dlatego nasi poprzednicy, których pamięć zawsze będzie błogosławiona, pozwolili Dalmatom, by w obrzędach i wszelkich świętych czynnościach używali swego ojczystego języka, to jest illyryjskiego,

Zaiste! Najdostojniejsi Ojcowie! Więcej herezyj, jak to $\mathrm{z}$ historii i z soborów wiadomo i nasze czasy także o tym mówią, zrodziła nam erudycja i nauka, aniżeli prostota i ignorancja ludzi bez wykształcenia, a nigdy jednak $z$ tego powodu nie zakazano ani nie potepiono nauki! Czytajmy więc na chwałę Chrystusa nie brudnymi rękami, lecz religijnie i w czystości, nie tylko po hebrajsku, grecku, czy łacinie, lecz także w języku ludowym, stosownie do pojęcia każdego Jezusa Chrystusa, w którym nie ma już ani żyda ani greka ani łacinnika ani prostaczka (vulgaris). Język bowiem ludowy jest także darem Ducha Św. i Jezusa Chrystusa, który w Swej łaskawości jest z nami aż do skończenia świata. I żaden wiek, żadna płeć, 'w ogóle nlikt niech nie doznaje przeszkody w czytaniu Pisma św. Dusza bowiem każdego sprawiedliwego jest siedzibą mądrości i każde pobożne serce, każdy miłośnik Chrystusa. może być jego biblioteką. Życzeniem moim byłoby, by do miejsc trudnych i wątpliwych pobożni i uczeni mężowie, wybrani do tego przez Synod, dodali adnotacje, w których zwróciliby uwagę czytelnikom tak na niejasność, jak i trudność danego tekstu. Na koniec w streszczeniu podaje me zdanie: Niech wszelkie pokolenie, język, lud i naród zajmuje się Chrystusem, niech Go czyta i miłuje i cokolwiek tchnie, niechaj Go wysławia!

Dekret zaś niech brzmi: ,Zakazujemy wszelkich skażonych wydań Pisma św. w języku ludowym i niech na przyszłość nie będą druko- 
wane bez pozwolenia Ordynariusza pod karami... a drukowane niech nie będą sprzedawane bez jego pozwolenia pod cenzurami etc..."

Podobne uwagi o czytaniu Pisma św. 'w języku ludowym podał w swym przemówieniu teolog Gentianus Hervetus który tak samo radził przekładać Pismo św. na języki nowożytne. $Z$ jego dłuższego przemówienia (Conc. Trid. XII. 530-6) warto przytoczyć niektóre zdamia końcowe, w których wystąpił przeciw tym wszystkim teologom, którzy nie chcieli zgodzić się na czytanie Pisma św. przez prostaczków w ich ojczystym jẹzyku. Według niego: Chrystus zaprasza wszystkich do Siebie, nie powinniśmy wiẹc nikomu zagradzać drogi do Niego. Pragnie On bowiem, by dziatki przychodziły do Niego i my podobnie nie pówinniśmy przeszkadzać tym, którzy przez czytanie Pisma św. chcą się zbliżyć do Niego. Św. Paweł chwali Týmoteusza, że już od wezesnej młodości nauczył się Pisma św. i dlatego choć młodzieńca uznał go za godnego piastowania świętego urzędu biskupiego, a my mielibyśmy nie tylko dzieci i młodzież, ale ludzi wszelkiego wieku i stanu z małymi wyjątkami powstrzymywać od czytania Pisma św.? Pozwalamy im na czytanie bezbożnych i rozwiązłych książek, a nie wstyd nam zakazywać chrześcijanom czytania nauki Chrystusowej!? Lecz jakimi dowodami popierają oni swoje zdanie? Mówią, że nie należy pereł rzucać przed wieprze, jak gdyby wieprzami należało nazywać tych, którzy odkupieni krwią Chrystusa na nowo narodzili się przez świętą wode odrodzenia? Jeżeli zaś św. Piotr nazywa wiernych królewskim kapłaństwem i narodem świętym, to nikt nie powinien ich nazywać - już nie mówię - wieprzami, ale profanami!

Słyszy się zarzut, że do miejsca świętego tylko kapłanom wolno było wchodzić, zapominają jednak o tym, że Biblia napisana była w ich ludowym języku. Twierdzą dalej, że katechumeni w starym Kościele zaliczani byli tylko do słuchających. Ale cóż w tym dziwnego, jeśli nie byli jeszcze wtajemniczeni i dlatego nie byli dopuszczani do sakramentów kościelnych, a słuchali tylko tego, co należało do ich chrześcijańskiego wykształcenia? Zresztą Pismo święte mogli z pożytkiem czytać $i$ to $z$ pożytkiem nawet poganie, czego dowodem ów eunuch, który, gdy ezytal proroka Izajasza, pouczony o znaczeniu czytanych przez niego słów przez diakona Filipa, został przez niego ochrzczony w imię Jezusa Chrystusa.

Największym i najsilniejszym argumentem przeciwników czytania Pisma św. przez prosty lud jest ta okoliezność, że skutkiem czytania Pisma św. przez nieuświadomionych czytelników świeckich powstają herezje. Hervetus wykazuje natomiast na podstawie historii, że twór- 
cami herezyj, począwszy od Ariusza, nie byli wcale prostaczkowie, lecz biskupi, kapłlani i w ogóle ludzie uczeni. Jeśli zaś tak jest w rzeczywistości, to nie chciejmy (pisze Hervetus), na prosty i niewinny ludek zwalać wielkie grzechy innych". Co się zaś tyozy tej tak bardzo niebezpiecznej sekty, która niestety opanowała już wielką część Europy, to prawdziwa jej przyczyna i początek leży głównie w tym, że bardzo mało biskupów spełniało swoje obowiązki, że kazaniami ii napomnieniami nie utrzymywali ludu w jego obowiązkach, nie wiedzieli nieraz, gdzie właściwie bich trzoda się znajduje, kapłani zaś odrzucili naukę Pańską i nie głosili wcale kazań albo na kazaniach zamiast uczyć nauki Chrystusa, nauczali świeckiej filozofili albo bajek babskich... Ale Chrystus ulitował się nareszoie nad colą ludu swojego li jak ze strasznej zbrodni Judasza stworzył zbawienie rodzaju ludzkiego, tak i z tych obecnych wielkich nieszczęść sprowadził dwie wielkie korzyści dla nas, a mianowicie: 1) wszyscy już rozumieją, że Pismo święte nalcży głosić czyste i szczere; 2) a biskupi widzą, że zbawienie i ocalenie religii chrześcijańskiej zależy przede wszystkim od ich świętego spełniania obowiązków i od przywrócenia upadłej karności kościelnej do jej pierwotnej godności.

Powinien zatem (zdaniem Herveta) lud chrześcijański Chrystusa poznawać bezpośrednio z Pisma świętego! A jeśli by przypadkeim zdarzyło się, że niektórzy prostaczkowie coś źle zrozumieli, to z tego tylko powodu nie należy powstrzymywać ludu od czytania Pisma św. w jego ojczystym języku. Pismo święte bowiem podobne jest do manny, która każdemu starczy obficie. W Piśmie św. moga zapełnić swój głód wiedzy do sytości ci, którzy oddają się rozważaniu rzeczy oderwanych od materii, a ci, którzy oddają się życiu czynnemu, znajdą w nim to wszystko, co prowadzi do prawego i uczciwego życia. Zgromadzenia mnichów i mniszek, nie znające obcych języków, znajdą w Piśmie św. uczeiwą i wielką rozkosz, dziewice i matrony szlachetne będą mogły czytać Pismo święte, zamiast bezwstydnych i niemoralnych bajek miłosnych, ludzie zaś rozporządzający wolnym czasem zamiast grywać w kości spędzać będą mogli miło czas na czytaniu Pisma św. Rolnicy znajdą w czytaniu Pisma św. pekrzepienie w Chrystusie w przykrościach swego życia, a młodzież znajdzie Chrystusa od zarania swego życia.

Należy się jednak postarać, by pracę nad przekładem ksiąg świętych powierzyé mężom uczonym i pobożnym. Jest rzeczą wprost nie do uwierzenia, ile korzyści przyniesie ta sprawa dla rzeczypospolitej chrześcijańskiej. A jeśli do tego dołączy się także to, że biskupi, pomni 
swego obowiązku, głosić będą ludowi słowo Boże, to nie wątpię, że doskonałe jego ziarno, powierzone dobrej glebie, wyda owoc $\mathrm{z}$ wielką lichwą ponad wszelką nadzieję i oczekiwanie ludzi. Ponieważ więc dla chwały Bożej będzie to bardzo piękne, a dla sprawy chrześcijańskiej bardzo pożyteczne, jeśli chrześcijanie czerpać będą Chrysstusa od samego Chrystusa, nie chciejcie zakazywać słuchania Chrystusa przemawiającego do wszystkich! Sprawcie to, aby Chrystus był w rękach, w ustach i w sercach wszystkich, by słusznie można było stwierdzić, że królestwo Boże istnieje w was, i nie dozwólcie twierdzić nieuczciwym, że, mając klucz wiedzy, ani sami nie weszliście, ani téz innych nie wpuszczacie; nie dozwólcie równiė, by dłużej miał być ukrywany Chrystus, w którym są ukryte niewypowiedziane skarby mądrości, które mogą nawet tysiące światów wzbogacić. Jemu z Ojcem i z Duchem Świętym niech będzie cześć i chwała na wieki wieków, Amen".

$\mathrm{Z}$ powyższych słów obu uczestników soboru trydenckiego widac doskonale, że Kościół nie był przeciwnikiem czytania Pisma św. w języku ojczystym i mimo pewnego niebezpieczeństwa, jakie grozić mogło wierze prostaczków skutkiem czytania Biblii w języku ludowym, synod nie wydał wcale zakazu czytania przekładów Pisma św. w językach nowożytnych. Przekłady te - rzecz jasna - miały według dekretu soboru być zatwierdzone przez odnośnego biskupa miejscowego. Po soborze trydenckim wychodziły, co prawda, za papieży Pawła IV, Piusa IV i Sykstusa V dekrety, ograniczające czytanie Pisma świętego 'w językach ludowych, ale nie miały one wszędzie zastosowania. I tak np. w Niemczech wierni katolicy mogli czytać Pismo św. w języku niemieckim w przekładach katolickich Ecka i Dietenbergera bez uprzedniego pozwolenia swych biskupów. Podobnie w Polsce wierni mogli czytać polski przekład Wujka i nie potrzebowali prosić o osobne pozwolenie.

Od czasów papieża Leona XIII zniknęły w Kóściele wszelkie dotychczasowe ograniczenia czytania Pisma św, w języku ludowym, przekłady jednak Pisma św. na język ojezysty muszą mieć już to aprobatę papieską już to biskupią i do przekładu Pisma św. muszą być dołączone objaśnienia, zaczerpnięte $\mathrm{z}$ dzieł Ojców Kościoła i z uczonych pisarzy katolickich.

Ostatni papieże, począwszy od Leona XIII, zachęcają bardzo wiernych do czytania Pisma św. N. T., a zwłaszcza Ewangelii. Co sądzi obecnie nam panujący Ojciec święty o czytaniu Pisma św., a zwłaszcza Nowego Test. przez wiernych, o tym dowiadujemy się z Jego encykliki z 30 września 1943 r.: „Divino afflante Spiritu“. I on, podøbnie jak 
jego poprzednicy, zachęca wiernych do poznania Chrystusa przez czytanie N. T., zwłaszcza Ewangelij. Pod koniec encykliki czytamy takie słowa:

„,Sprawce zbawienia, Chrystusa, ludzie tym pełniej poznają, tym goręcej pokochają, tym wierniej będą naśladować, im usilniej zostaną pobudzeni do poznawania i rozważania Pisma św., szczególnie Nowego Testamentu. Albowiem, jak mówi św. Hieronim: ,.Nieznajomość Pisma świętego jest nieznajomością Chrystusa“, oraz: ,.Jeżeli co podtrzymuje męża roztropnego w tym życiu i przekonywa, żeby wśród ucisków i burz tego świata zachował równowagę ducha, sądzę, że jest to przede wszystkim rozmyślanie i znajomość Pisma św. Stąd zaczerpną pociechy i mocy Bożej do cierpliwego znoszenia przeciwności ci, których dotknęło nieszczęście i gnę̧ią uciski; tu, to jest w Ewangeliach, wszystkim ukazuje się Chrystus jako najwyższy i najdoskonalszy wzór sprawiedliwości, milości i miłosierdzia; tu też całemu rodzajowi ludzkiemu, rozdartemu i szarpanemu trwogą. stoją otworem źródła owej łaski Bożej, którą zarzuciły i zaniedbały narody i ich rządcy, i dlatego nie zdolaja doprowadzić świata do pokoju, ani pogodzić na stałe umysłów; tutaj wreszcie wszyscy poznają Chrystusa, ,który jest głową wszelkiego księstwa i zwierzchności“ i ,który stał się nam od Boga mądrością i sprawiedliwością i poświęceniem i odkupieniem“".

„Niech się żywią tym pokarmem umysły wiernych, i niech zeń czerpią poznanie i miłość Boga oraz postęp i szczeście własnej duszy. Niechże więc wykładacze słowa Bożego całą duszą oddadzą się temu świętemu zadaniu“. ,Niech się modlą, by zrozumieé" niech pracują, by z dniem każdy coraz to głẹbiej wnikać w tajemnice tych świętych stronic, niech nauczają i głoszą kazania, by również innym otworzyé skarby słowa Bożego" $\left.{ }^{1}\right)$.

Idąc po myśli życzeń Stolicy Apostolskiej bibliści polsçy dali społeczeństwu katolickiemu w Polsce w ubieglym roku dwa nowe przekłady Pisma św. w języku polskim. I tak Ks. Dr Eug. Dąbrowski wydał cały N. T. z tekstu Wulgaty, a Ks. Gryglewicz Ewangelie i Dzieje Apostolskie z tekstu greckiego. Oba przekłady mają swe wartości i zalety (obok nieuchronnych braków i usterek). Chodzi teraz tylko o to, by duchowieństwo polskie zaznajomilo się $\mathrm{z}$ nimi i by według możności przyczyniło się ze swej strony do ich rozpowszechnienia wśród ludu wiernego.

Ks. Piotr Stach.

1) Przeklad oficjalny Encykliki (Rzym 1943), s. 25-26). 